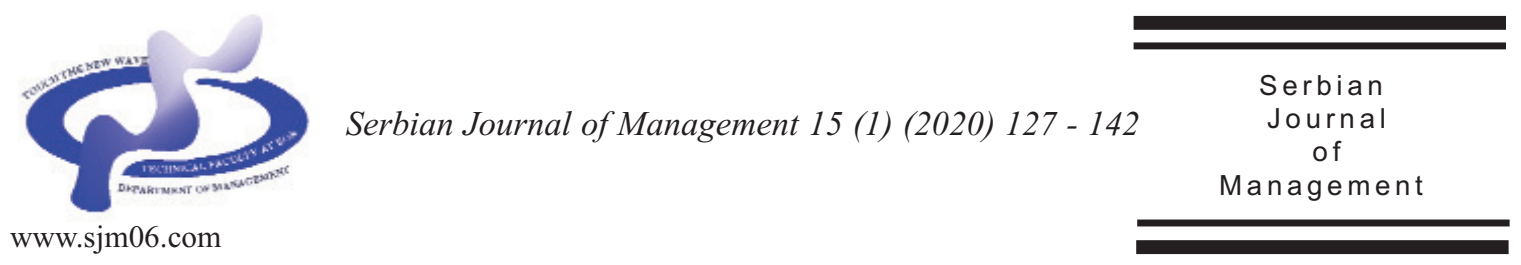

\title{
BUSINESS PROCESS IMPROVEMENT OF THE WASTEWATER TREATMENT: REDUCING THE RISK OF ENVIRONMENTAL POLLUTION
}

\author{
Blaženka Piuković Babičkovića , Željko Vojinovićb, Bojan Lekovićb*, \\ Drago Cvijanovićb ${ }^{b}$ Otilija Sedlak ${ }^{b}$ and Zoran Ćirićb

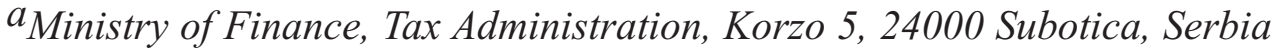 \\ ${ }^{b}$ University of Novi Sad, Faculty of Economics in Subotica, Segedinskiput 9-11, \\ 24000 Subotica, Serbia
}

(Received 03 May 2018; accepted 08 March 2019)

\begin{abstract}
The Republic of Serbia is in the group of European countries, which have evident problems regarding the wastewater treatment. The main goal of the entire research is to point out the future of the process organization, as well as the correlation between the conduction of a concept of business processes and achieved performances management, based on a specific example of wastewater treatment. For the process of wastewater treatment, this paper will represent a "AS-IS" model that was applied in the conditions of functional organizational structure, and a "TO-BE" model, which was applied within the process orientation. For both of the models a review of the achieved parameters will be given, obtained by the application of the mentioned models. The given parameters indicate the presence of pollutants in wastewater after the conducted treatment process, with a description on how it reflected on the risk of environmental pollution. The innovated model of wastewater treatment achieves significantly better results, which is of great importance for environmental protection. Concrete evidence of the increase of chemical oxygen demand (COD), biological oxygen demand (BOD), total nitrogen (TN), total phosphorus (TP), total suspended solids (TSS) removal with the use of these models is shown in this paper.
\end{abstract}

Key words: wastewater treatment, business process, risk, environmental protection.

1. INTRODUCTION

Drinking water production and wastewater treatment are both of crucial importance for the life on planet Earth. This is why the subject of this paper deserves special attention from society. According to OUN data, 1.5 billion people do not have

\footnotetext{
* Corresponding author: bojan.lekovic@ef.uns.ac.rs
}

DOI: $10.5937 /$ sjm15-17334 
access to clean drinking water and in the next 25 years this number will increase to 5.4 billion (Piuković Babičković et al., 2016). These data point to a certain global problem, which has to be solved in a thoughtful, planned and organized way.

Public enterprises engaged in the wastewater treatment in the Republic of Serbia face many problems. According to the fiscal strategy for the year 2017, which was adopted by the Republic of Serbia government, the operations of public enterprises were a significant source of fiscal risks, both the budget revenues and on the expenditure side. However, public enterprises face many problems in their operations, from debt collection to full settlement of obligations to creditors, the state and employees.

In the Program of economic reforms for the period 2017-2019, which was approved by the Government of the Republic of Serbia, in the field of research and innovation, they identified several key problems. These are low total funds for science and research, highly educated population leaving the country, insufficient cooperation between science and economy about innovative projects, lack of institutional framework for the support to innovation, etc.

The Republic of Serbia is in the group of European countries that continuously meet many problems concerning the wastewater treatment and the great risk of environmental pollution. According to the Strategy of Wastewater Management for the period 2010-2019, passed by the government of the Republic of Serbia, only $46 \%$ of households are connected to sewage system, while the amount of municipal wastewater is 363.1 million $\mathrm{m} 3$ annually. A devastating data is that of the total amount of wastewater 5.3\% is only treated in a proper way, while the generated sludge after the wastewater treatment is disposed of in landfills (Official Gazette of RS no. 29/10). All of these point out the great risk of environmental pollution. Due to all mentioned above, the need of accepting new skills, new technologies, innovation in organization and managing enterprises, should be evident to our water treating enterprises (Ahmetagić et al., 2011). Events management, as a field of industrial practice, can be defined as organization and coordination of activities necessary for achieving the event goals (Bladen et al., 2012).

\section{THEORETICAL BACKGROUND}

\subsection{Introduction of a Process Approach in Organization}

Recognized world theorist Drucker points out that organization must be a key subject of changes, while the most effective way to manage changes successfully is that changes initiate by themselves (Drucker, 2005). Porter M.E. (1985) emphasized the need for managing processes, as well as the need for tracking and measuring the set goals, at the level of a whole process and sub-processes, activities and specific tasks. When moving to process orientation, managers need to conduct serious analyzes to determine the aspects of process performance by indicators that are most relevant to achieving overall organizational goals (Hammer \& Stanton, 2001).

Owing to the essential shortage of functional access, which reflects in control rigidity, absence of innovation, as well as in the conflict with the projected tasks, the process approach is becoming more and 
more popular in management (Kravčenko \& Mešalnik, 2011). The evolution of an enterprise and in general of all institutions, regardless of whether it is a profitable or non-profit organization, leads to the introduction of a process-oriented organization (Crosetto \& Macazaga, 2005). Processes play a central role in the organizational system because they associate other components of the organization (Burlton, 2001). There is a very different perspective of business process observation and an extremely wide range of techniques and tools used in the process organization (Darnton \& Darnton, 1997).

The process orientation is a main tool for the process evaluation and studying the methods in which processes can be created, restructured and managed in order to improve performances (Anupindi et al., 2012).

For many organizations, the Business Process Management (BPM) is one of the most important subjects, because it is a concept that, if adopted successfully, can bring significant benefits to an organization, such as better understanding of business processes, a higher level of control, and significantly better achieved business results (Buh et al., 2015). Due to the popularity of the very concept of business processes, many companies are called process-oriented (Haggstrom \& Oscarsson, 2001), But the process orientation, in addition to being a great opportunity for the organization, also requires a complete engagement of management, without which the process initiatives do not achieve the expected result (Lindfors, 2003). The fundamental changes in business processes affect many other parts and aspects of the organization - in fact, on all of its parts (Hammer \& Champy, 2004).

In order to evaluate and improve business processes performances, it is important to measure it quantitatively. Managing business processes implies the management according to defined performances. Binner (2011) pointed out new managerial occupations necessary for the successful realization of a concept of business processes management, which already exist in the Anglo-Saxon world. These are business process analysts (Business Analyst) and business process trainers (Business Process Professional). The performances are target values that are defined by management or the business processes analysts, and management and method of realization of those is in the field of the business processes professionals, i.e. the managerial process teams, which include the owners of key processes and subprocesses (Ahmetagić et al., 2012). In realization of the business process, managerial concept employees get new roles or the current roles change significantly (Eicker et al., 2008). Management of key processes is possible to realise only if there exists a cross-functional cooperation between managers from all parts of the process. This is achieved by forming a team of process managers that consists of persons in different parts of the process, who ought to have knowledge of their own work processes, as well as jurisdiction to change the work methods within their own functions (Rentzhog, 2000).

Adequate implementation of the business processes management in enterprises that are engaged in wastewater treatment, would result in the continuous management of business processes, which would realise through constant monitoring and evaluation of the processes, implementation of redesign and the achievement of better performances. Everything previously mentioned is invaluable for environmental protection, 
without adequate control and monitoring of the wastewater treatment process. Only careful control and monitoring of the process will give the specified values.

2.2. Wastewater Treatment by the Use of "AS-IS" model

In the enterprise $\mathrm{PUC}^{1}$,Waterworks \& Sewerage" Subotica, an overview was done of the wastewater treatment process. The results achieved by the use of ,AS-IS“ model in the period 1995-2009, while the enterprise was functionally organized, are given in table 1 . The process of wastewater treatment comprised three sub-processes:

(1) Wastewater disposal;

(2) Mechanical treatment of wastewater;

(3) Biological treatment of wastewater.
The analysis of achieved performances of wastewater treatment by the use of "AS-IS" model shows the increased risk regarding environmental pollution. Many obstacles, imperfections and problems have been noted in realisation of the business process. The biggest problem was the fact that the treated wastewater did not meet the required standards. The recipient of the discharged effluent is Lake Palic, which suffered greatly, as the discharged water contributed to its pollution. A review of achieved performances by the use of „AS-IS" model in the period from 1995-2009, is given in table 1 .

COD: Chemical Oxygen Demand - a measure of the capacity of water to consume oxygen during the decomposition of organic matter and the oxidation of inorganic chemicals such as ammonia and nitrite

Table 1. Achieved percentages of deposition from waste water by the use of "AS-IS model" Source: PUC "Wasterworks\&Sewerage" Subotica, 2017

\begin{tabular}{|c|c|c|c|c|c|}
\hline Year & $\begin{array}{c}\text { COD } \\
\text { (regulated } \\
\text { efficiency } \\
75 \% \text { ) }\end{array}$ & $\begin{array}{c}\text { BOD } \\
\text { (regulated } \\
\text { efficiency } \\
70-90 \% \text { ) }\end{array}$ & $\begin{array}{c}\text { Total nitrogen } \\
\text { (regulated removal } \\
\text { efficiency } \\
\mathbf{7 0 - 8 0 \% )}\end{array}$ & $\begin{array}{c}\text { Total phosphorus } \\
\text { (regulated } \\
\text { removal } \\
\text { efficiency } 80 \% \text { ) }\end{array}$ & $\begin{array}{l}\text { Suspended solids } \\
\text { (regulated removal } \\
\text { efficiency } 90 \% \text { ) }\end{array}$ \\
\hline & $\begin{array}{l}\text { Achieved } \\
\text { efficiency }\end{array}$ & $\begin{array}{l}\text { Achieved } \\
\text { efficiency }\end{array}$ & $\begin{array}{c}\text { Achieved removal } \\
\text { efficiency }\end{array}$ & $\begin{array}{c}\text { Achieved removal } \\
\text { efficiency }\end{array}$ & $\begin{array}{c}\text { Achieved removal } \\
\text { efficiency }\end{array}$ \\
\hline & $\%$ & $\%$ & $\%$ & $\%$ & $\%$ \\
\hline 1995 & 64.73 & 75.47 & 22.76 & 31.76 & - \\
\hline 1996 & 76.03 & 72.03 & 13.39 & 18.45 & - \\
\hline 1997 & 86.50 & 85.83 & 21.67 & 31.21 & - \\
\hline 1998 & 74.54 & 84.84 & 21.46 & 18.75 & - \\
\hline 1999 & 90.28 & 88.45 & 21.43 & 30.58 & - \\
\hline 2000 & 78.28 & 87.44 & 26.78 & 35.88 & - \\
\hline 2001 & 77.33 & 85.41 & 27.01 & 30.00 & - \\
\hline 2002 & 78.30 & 85.86 & 24.55 & 30.76 & - \\
\hline 2003 & 81.43 & 89.89 & 30.72 & 37.58 & 80.00 \\
\hline 2004 & 78.63 & 89.69 & 24.88 & 37.03 & 77.85 \\
\hline 2005 & 82.11 & 90.88 & 26.38 & 42.74 & 86.47 \\
\hline 2006 & 80.78 & 92.64 & 26.93 & 38.67 & 87.00 \\
\hline 2007 & 81.51 & 91.05 & 29.72 & 42.32 & 83.01 \\
\hline 2008 & 81.69 & 91.71 & 29.64 & 48.48 & 84.71 \\
\hline 2009 & - & 92.75 & 48.07 & 55.88 & - \\
\hline
\end{tabular}

1 PUC - Public Utility Company 
BOD: Biological Oxygen Demand - a measure of oxygen-demanding strength of wastewaters, measuring the amount of oxygen consumed by microbial oxidation and is most relevant to waters rich in organic matter

A review of the achieved removal efficiency of the five most important matters from wastewater, in regard to a regulated removal efficiency is given in the table 1 . It is clearly seen that during the presented period of 15 years, the efficiency of the wastewater treatment was not as high as the standards required. During this period, only some of the five key parameters were measured, as can be seen in table 1. It is clear that the process was not monitored adequately. In addition, the sludge produced during the wastewater treatment process was not treated, but only disposed in liquid form. Although the sludge is a potential threat for the environment, less attention is paid to its treatment than to the wastewater treatment process (Naumenko, 2012).

\subsection{The use of Innovated "To-Be" Model for Wastewater Treatment}

In order to eliminate shortcomings and causes of organizational poor performances, besides changes focused on the structural elements of organization, it is necessary to observe an organization as a network of business processes, and according to implemented process analysis to implement changes and the improvement of business processes (Janićijević, 2010). Nanz (2011) pointed out that there is a requirement to implement an analysis of project environment, clearly defined demarcation, the scope and content of a project, and pointed out that conditions have to be known in advance, and not to be defined during the project. According to O. Rentzhog (2000), it is necessary to divide the process into logical parts in order to understand the current process and the way it works. In accordance with the previously mentioned after the implemented analysis the innovated ,TO$\mathrm{BE}^{\text {" }}$ model was defined.

The innovated process of wastewater treatment comprises a water line and a sludge line.

The water line was changed and greatly improved to ensure a more efficient wastewater treatment. The treatment process is comprised of the following sub-processes:

(1) Wastewater disposal

(2) Mechanical treatment of wastewater

(3) Biological treatment of wastewater.

The sludge line represents the treatment of primary and secondary sludge removed from the wastewater treatment process:

(1) Primary and secondary sludge thickening

(2) Anaerobic digestion of sludge

(3) Energy production.

The innovated process is monitored and controlled by the SCADA system (Supervisory Control and Data Acquisition SCADA). Ostroff (1999) has pointed out the significance of information technology and its use in a process-oriented organization, while it provides easier, simpler and faster monitoring and process operation. Thanks to the use and support of IT system, enterprises and specialized departments can focus better to its basic processes and competences, and a faster information flow was provided, which has led to the process improvement and development of competitive advantage (Kuhn, 2011). For this reason, monitoring the process of wastewater treatment by the 
SCADA system records is an important progress compared to the previous method of monitoring and documenting of business process (Piuković Babičković et al., 2016).

Innovation in sub-processes of the wastewater treatment and in the measurements carried out during all these activities, resulted in a more efficient treatment process. All these improvements are now followed and recorded continuously in a modern way, by the SCADA system.

Better monitoring and control in the subprocesses were possible due to clearly specified performance values, units of measures, initial values, target values, frequency of measurements and measuring/control points.

In the innovated process of wastewater treatment, the output from the process is treated wastewater, absolutely in accordance with the regulated standards. In order to decrease the risk from environmental pollution, in this innovated process of wastewater treatment special attention is paid to sludge. Therefore the following has to be done: primary sludge thickening in a gravity thickener, secondary sludge thickening on a gravity belt thickener, anaerobic sludge digestion of the thickened sludge for sludge stabilization, biogas production, use of biogas for energy production in a gas engine, dewatering of stabilized sludge on a belt filter press. The product from the sub-process is stabilized sludge with $20 \%$ of dry matter and biogas. The measurements include wastewater quantity and quality, and the dry matter contents of the sludge produced in the treatment process. Online measurements are also used for anaerobic sludge digestion control, during sludge stabilization and biogas production. The quality and quantity of the produced biogas are both very important, because of the gas engines (CHP units $^{2}$ ) used at the wastewater treatment plant. These engines use the biogas from the process and produce electrical and thermal energy, both of which are used in the

Table 2. Achieved efficiencies using the „TO-BE“ model-annual averages

\begin{tabular}{cccccc}
\hline Year & $\begin{array}{c}\text { COD } \\
\text { (Regulated } \\
\text { efficiency 75\%) }\end{array}$ & $\begin{array}{c}\text { BOD } \\
\text { (Regulated } \\
\text { efficiency } \\
\mathbf{9 0 \% )}\end{array}$ & $\begin{array}{c}\text { Total nitrogen } \\
\text { (Regulated } \\
\text { removal efficiency } \\
\mathbf{7 0 - 8 0 \% )}\end{array}$ & $\begin{array}{c}\text { Total phosphorus } \\
\text { (Regulated removal } \\
\text { efficiency 80\%) }\end{array}$ & $\begin{array}{c}\text { Suspended matter } \\
\text { (Regulated removal } \\
\text { efficiency 90\%) }\end{array}$ \\
\cline { 2 - 6 } & $\begin{array}{c}\text { Achieved removal } \\
\text { efficiency }\end{array}$ & $\begin{array}{c}\text { Achieved removal } \\
\text { efficiency }\end{array}$ & $\begin{array}{c}\text { Achieved removal } \\
\text { efficiency }\end{array}$ & $\begin{array}{c}\text { Achieved removal } \\
\text { efficiency }\end{array}$ & $\begin{array}{c}\text { Achieved removal } \\
\text { efficiency }\end{array}$ \\
\cline { 2 - 6 } $\mathbf{2 0 1 0}$ & 92.17 & $\mathbf{9 6 . 3 3}$ & $\mathbf{6 5 . 2 3}$ & $\mathbf{7 6 . 0 6}$ & $\mathbf{9 5 . 6 8}$ \\
$\mathbf{2 0 1 1}$ & 93.32 & 97.33 & 75.54 & 89.99 & 97.23 \\
$\mathbf{2 0 1 2}$ & 95.35 & 97.53 & 77.00 & 93.25 & 97.74 \\
$\mathbf{2 0 1 3}$ & 94.01 & 97.57 & 80.85 & 88.08 & 96.61 \\
$\mathbf{2 0 1 4}$ & 96.56 & 98.45 & 85.38 & 92.03 & 98.20 \\
$\mathbf{2 0 1 5}$ & 95.16 & 98.30 & 86.53 & 93.06 & 97.47 \\
\hline $\mathbf{2 0 1 6}$ & 95.51 & 98.26 & 85.03 & 94.57 & 97.85 \\
\hline
\end{tabular}

\footnotetext{
${ }^{2} \mathrm{CHP}$ - Combined heat and power unit
} 
treatment process. The electrical energy obtains about $50 \%$ of the total consumption of this energy of the plant intended for wastewater treatment, and this means a significant saving for the enterprise (Piuković Babičković et al., 2016).

In the specific enterprise, where research has been carried out since 2000, the first steps have been taken towards the introduction of process organizational structure, and therefore in accordance with the mentioned, the identification and definition of business processes. Regarding the wastewater treatment, this enterprise has achieved significant results by the use of innovated process of wastewater treatment, while meeting all the necessary terms for obtaining the ISO quality standards. In the next table, results achieved in the period from 2010 to 2016 are presented.

\section{COMPARATIVE ANALYSIS OF THE TRADITIONAL AND THE INNOVATED WASTEWATER PROCESSES}

Data presented in Tables 1 . and 2 point to the conclusion that the implementation of the "TO-BE" model achieves better results compared to the use of the "AS-IS" model, and values are mainly over the desired minimal-regulated values of removal. Application of the "TO-BE" model contributes to environmental protection for the outcomes are purified water meeting required standards, stabilized sludge containing $20 \%$ of dry matter and electric and thermal energy.

Comparative analysis of performances of using these two models was accomplished by testing the difference between the means of the given five indicators, namely between data for the period 2010-2016 ("TO-BE" model) and data for the period 1995-2009 ("AS-IS" model). For two indicators - COD and suspended matters- the analysis was performed for shorter period due to missing data. Testing results are shown in the next tables. Statistically significant is the difference between means for the error term less than 0.05 and statistically highly significant for the error term less than 0.01 .

All the five indicators show improvement: t-statistics are greater than critical values, and probabilities are less than 0.01 . It can be concluded that the average values of achieved efficiency in water purification process statistically highly significantly greater when applying the innovative "TO-BE" model compared to the application of the traditional "AS-IS" model.

Table 3. Difference between means of achieved efficiency for COD in the periods 19952009 and 2010-2016

\begin{tabular}{llcc}
\hline No & Statistics & \multicolumn{2}{c}{ Period and applied model } \\
\hline & & 1995-2009 & 2010-2016 \\
\cline { 3 - 4 } 1 & Number of observations $\left(\mathrm{n}_{\mathrm{i}}\right)$ & ,AS-IS“ & „TO-BE“ \\
\cline { 3 - 4 } 2 & Average value $\left(\overline{\mathrm{x}}_{i}\right)$ & 79.44 & 7 \\
& \multicolumn{2}{c}{94.58} \\
3 & Standard deviation $\left(\sigma_{\mathrm{i}}\right)$ & 5.88 & \multicolumn{2}{c}{1.50} \\
4 & Difference between means & \multicolumn{2}{c}{15.14} \\
5 & Standard error of difference $\left(\mathrm{S}_{1-2}\right)$ & \multicolumn{2}{c}{2.27} \\
6 & Test statistics $(\mathrm{t})$ & \multicolumn{2}{c}{6.67} \\
7 & Error term - probability $(\mathrm{p})$ & \multicolumn{2}{c}{0.0000} \\
\hline
\end{tabular}


Table 4. Difference between means of achieved efficiency for BOD in the periods 19952009 and 2010-2016

\begin{tabular}{llcc}
\hline No & \multicolumn{1}{c}{ Statistics } & \multicolumn{2}{c}{ Period and applied model } \\
\hline & & $\begin{array}{c}1995-2009 \\
\text { "AS-IS“ }\end{array}$ & $\begin{array}{c}2010-2016 \\
\text { "TO-BE" }\end{array}$ \\
\cline { 3 - 4 } 1 & Number of observations $\left(\mathrm{n}_{\mathrm{i}}\right)$ & 15 & 7 \\
2 & Average value $\left(\overline{\mathrm{X}}_{i}\right)$ & 86.93 & 97.68 \\
3 & Standard deviation $\left(\sigma_{\mathrm{i}}\right)$ & 6.00 & 0.74 \\
4 & Difference between means & \multicolumn{2}{c}{10.75} \\
5 & Standard error of difference $\left(\mathrm{S}_{1-2}\right)$ & \multicolumn{2}{c}{2.30} \\
6 & Test statistics $(\mathrm{t})$ & \multicolumn{2}{c}{4.67} \\
7 & Error term - probability $(\mathrm{p})$ & \multicolumn{2}{c}{0.0001} \\
\hline
\end{tabular}

Table 5. Difference between means of achieved removal efficiency for nitrogen in the periods 1995-2009 and 2010-2016

\begin{tabular}{llcc}
\hline No & \multicolumn{1}{c}{ Statistics } & \multicolumn{2}{c}{ Period and applied model } \\
\hline & & $\begin{array}{c}1995-2009 \\
\text { "AS-IS“ }\end{array}$ & $\begin{array}{c}2010-2016 \\
\text { "TO-BE“" }\end{array}$ \\
\cline { 3 - 4 } 1 & Number of observations $\left(\mathrm{n}_{\mathrm{i}}\right)$ & 15 & 7 \\
2 & Average value $\left(\overline{\mathrm{X}}_{i}\right)$ & 26.36 & 79.36 \\
3 & Standard deviation $\left(\sigma_{\mathrm{i}}\right)$ & 7.42 & 7.55 \\
4 & Difference between means & \multicolumn{2}{c}{53.00} \\
5 & Standard error of difference $\left(\mathrm{S}_{1-2}\right)$ & \multicolumn{2}{c}{3.41} \\
6 & Test statistics $(\mathrm{t})$ & \multicolumn{2}{c}{0.0000} \\
7 & Error term - probability $(\mathrm{p})$ & \multicolumn{2}{c}{0.53} \\
\hline
\end{tabular}

Table 6. Difference between means of achieved removal efficiency for phosphorus in the periods 1995-2009 and 2010-2016

\begin{tabular}{llcc}
\hline No & \multicolumn{1}{c}{ Statistics } & \multicolumn{2}{c}{ Period and applied model } \\
\hline & & $\begin{array}{c}1995-2009 \\
\text { "AS-IS“ }\end{array}$ & $\begin{array}{c}2010-2016 \\
\text { "TO-BE“" }\end{array}$ \\
\cline { 3 - 4 } 1 & Number of observations $\left(\mathrm{n}_{\mathrm{i}}\right)$ & 15 & 7 \\
2 & Average value $\left(\overline{\mathrm{X}}_{i}\right)$ & 35.34 & 89.58 \\
3 & Standard deviation $\left(\sigma_{\mathrm{i}}\right)$ & 9.93 & 6.35 \\
4 & Difference between means & \multicolumn{2}{c}{54.24} \\
5 & Standard error of difference $\left(\mathrm{S}_{1-2}\right)$ & \multicolumn{2}{c}{4.12} \\
6 & Test statistics $(\mathrm{t})$ & \multicolumn{2}{c}{13.16} \\
7 & Error term - probability $(\mathrm{p})$ & \multicolumn{2}{c}{0.0000} \\
\hline
\end{tabular}

This applies to all five indicators. The highest relative improvement was achieved related to nitrogen (201\%) and phosphorus (153\%). Despite the lower improvement with suspended matter removal (17\%), this result is also important, for values being under the regulated efficiency in every year of application of the traditional model became higher than minimally required using the innovative model. COD and BOD efficiencies showed improvement as well (19\% and 12\%) although earlier years' performances were inside the required boundaries. 
Table 7. Difference between means of achieved removal efficiency for suspended matters in the periods 1995-2009 and 2010-2016

\begin{tabular}{llcc}
\hline No & \multicolumn{1}{c}{ Statistics } & \multicolumn{2}{c}{ Period and applied model } \\
\hline & & $\begin{array}{c}\text { 2003-2008* } \\
\text { "AS-IS“ }\end{array}$ & $\begin{array}{c}2010-2016 \\
\text { "TO-BE“" }\end{array}$ \\
\cline { 3 - 4 } 1 & Number of observations $\left(\mathrm{n}_{\mathrm{i}}\right)$ & 6 & 7 \\
2 & Average value $\left(\overline{\mathrm{X}}_{i}\right)$ & 83.17 & 97.25 \\
3 & Standard deviation $\left(\sigma_{\mathrm{i}}\right)$ & 3.64 & 0.86 \\
4 & Difference between means & \multicolumn{2}{c}{14.08} \\
5 & Standard error of difference $\left(\mathrm{S}_{1-2}\right)$ & \multicolumn{2}{c}{1.41} \\
6 & Test statistics $(\mathrm{t})$ & \multicolumn{2}{c}{9.99} \\
7 & Error term - probability $(\mathrm{p})$ & \multicolumn{2}{c}{0.0000} \\
\hline
\end{tabular}

* Data for 1995-2002 and 2009 not available

\section{DYNAMIC ANALYSIS OF PERFORMANCES OF THE INNOVATED WASTEWATER PURIFICATION PROCESS}

Tracking of wastewater purification process and measuring achieved performances were accomplished using the SCADA system. For the total period of the implementation of the "TO-BE" innovative system, there are precise monthly data about the results of water purification and achieved efficiency.

In the next figures, diagrams of monthly values of input and output for COD, BOD, nitrogen, phosphorus and suspended matter are given respectively. Data are given for every of 84 months of the observed sevenyear period 2010-2016. In the diagrams, the horizontal axis shows periods (months), in the left-hand side vertical axis there are units of input values given, and in the right-hand side vertical axis units for output values are shown. A horizontal fine line illustrates the required goal value of the output, input values are given with dotted polygonal line and a bold polygonal line represents output values.

The measured values of inputs and outputs of all the observed performances have noteworthy variations from month to month. Varation coefficinets (equalling proportion of standard deviation and average) have relatively high values, as shown in the next table.

High values of variation coefficients are result of strong variations as in input so in output values, particularly of presence of extreme input and output values. We explored and found extreme values applying Grubbs' test (Grubbs, 1969) with $p=0.05$ and degrees of freedom $n-2=82$.

Test statistics:

$G=\frac{Y_{\max }-\bar{Y}}{\sigma}$

where $Y_{\max }$ is the maximal observed value in the given sample, is the average and $\bar{Y}$ is the standard deviation.

Critical test value is computed by the formula:

$$
\frac{n-1}{\sqrt{n}} \sqrt{\frac{\left(t_{\alpha / n, n-2}\right)^{2}}{n-2+\left(t_{\alpha / n, n-2}\right)^{2}}}
$$

where $\mathrm{n}$ is the number of observations in the sample, $t_{a / n}, \mathrm{n}-2$ is the critical value of $t$ distribution at significance level $a / n$ and with degrees of freedom $n-2$. 


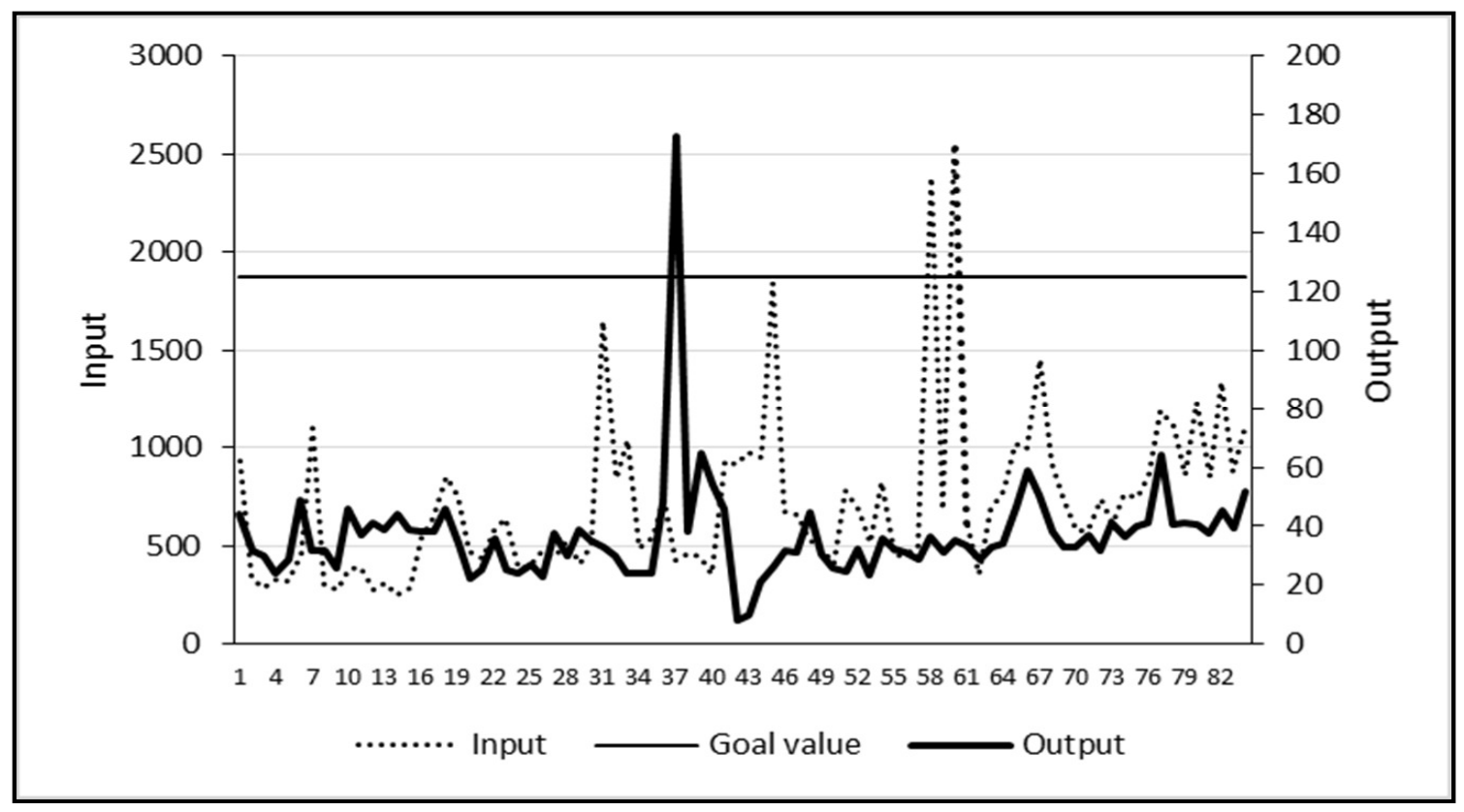

Figure 1. Monthly values of COD input and output (mg/l), 2010-2016

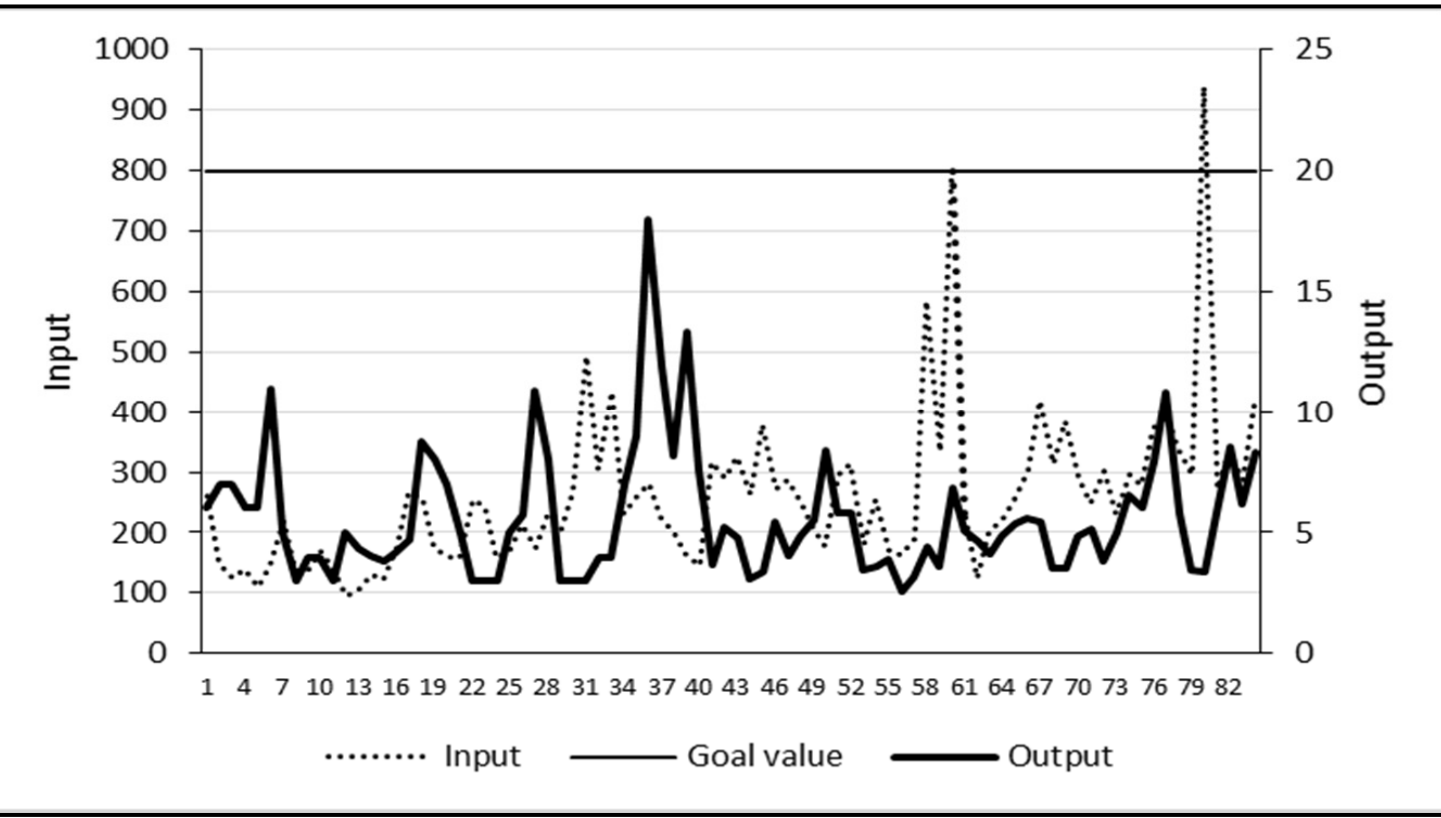

Figure 2. Monthly values of BOD input and output (mg/l), 2010-2016 


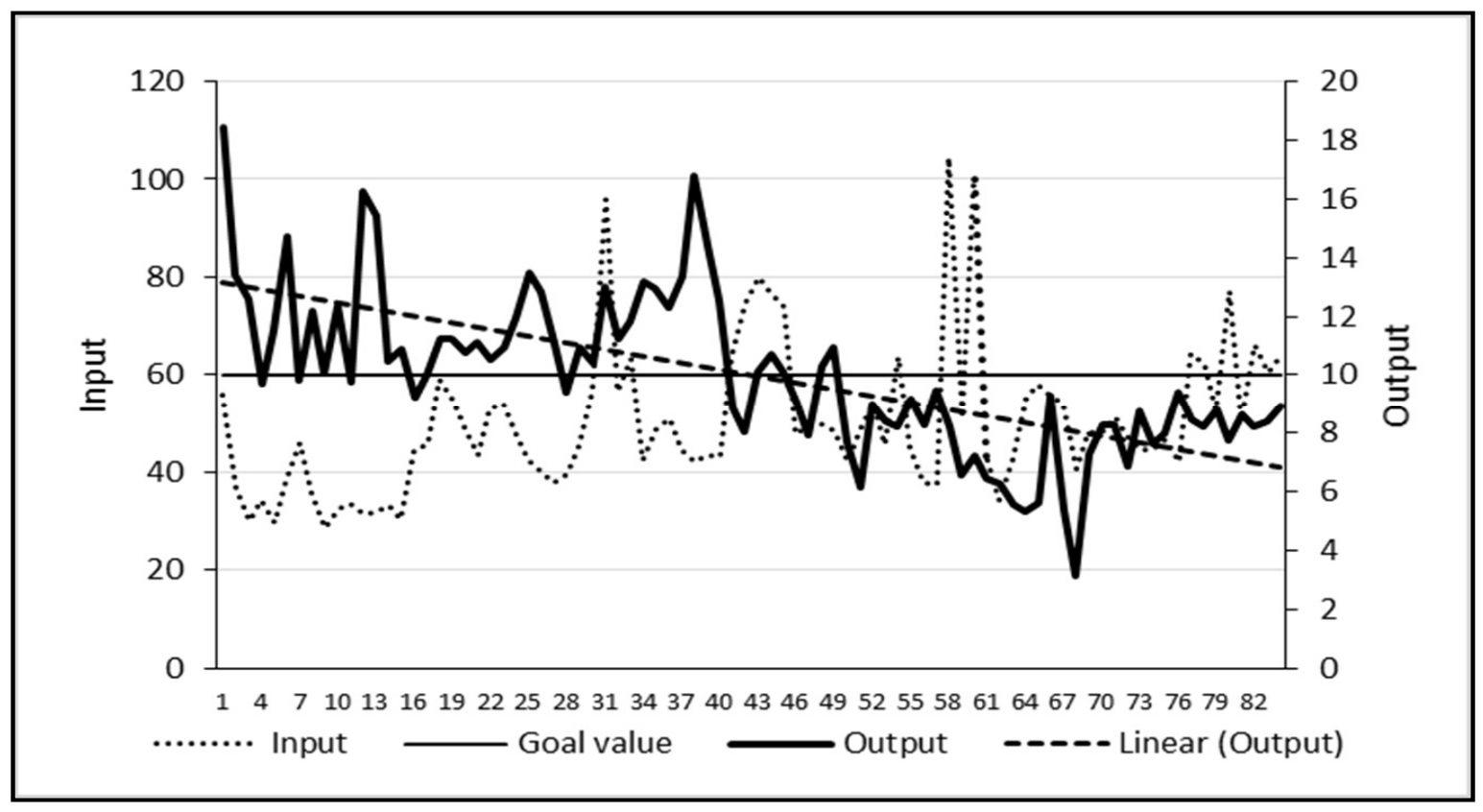

Figure 3. Monthly values of nitrogen input and output (mg/l), 2010-2016 dashed line represents significant decreasing trend of nitrogen output values

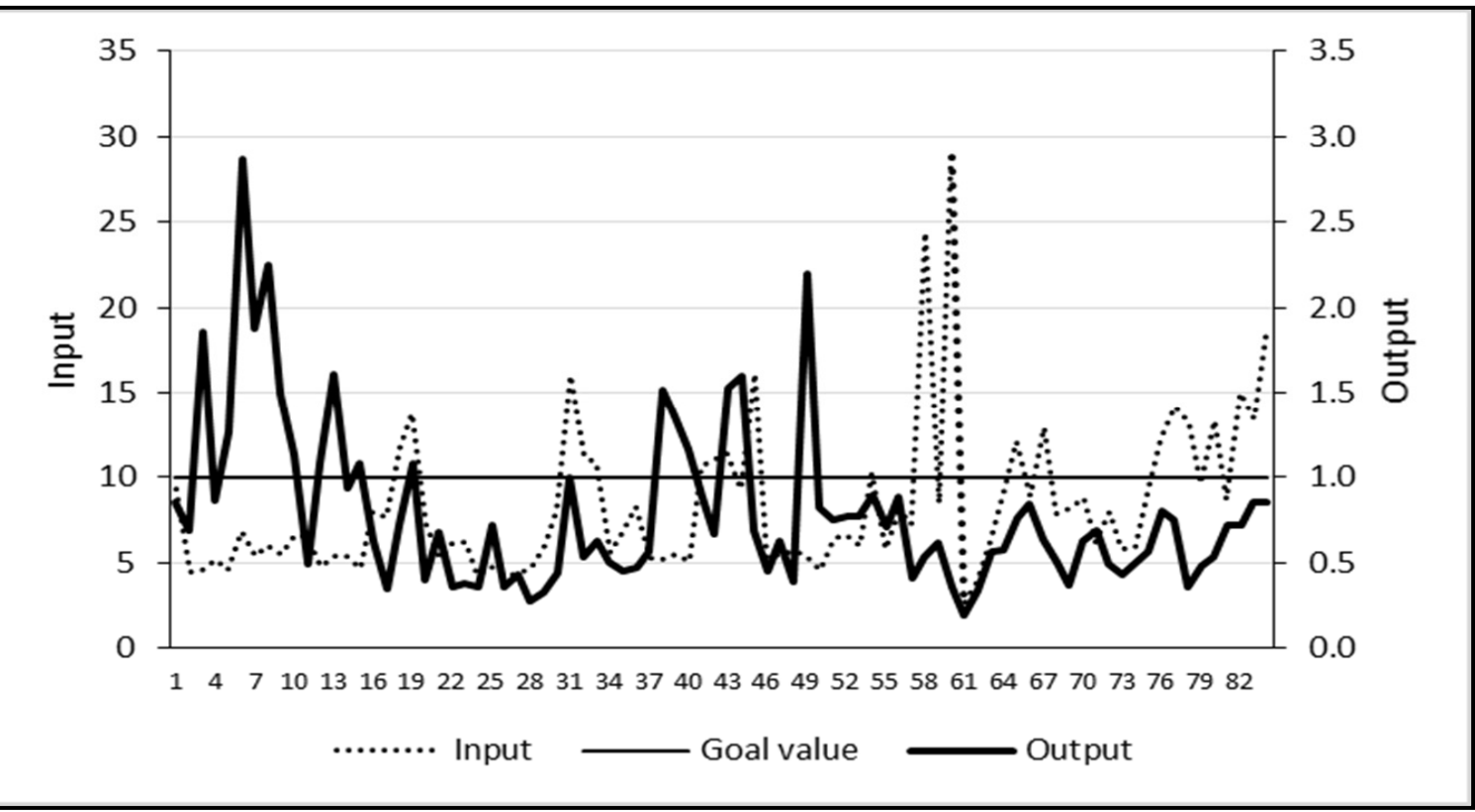

Figure 4. Monthly values of phosphorus input and output (mg/l), 2010-2016 


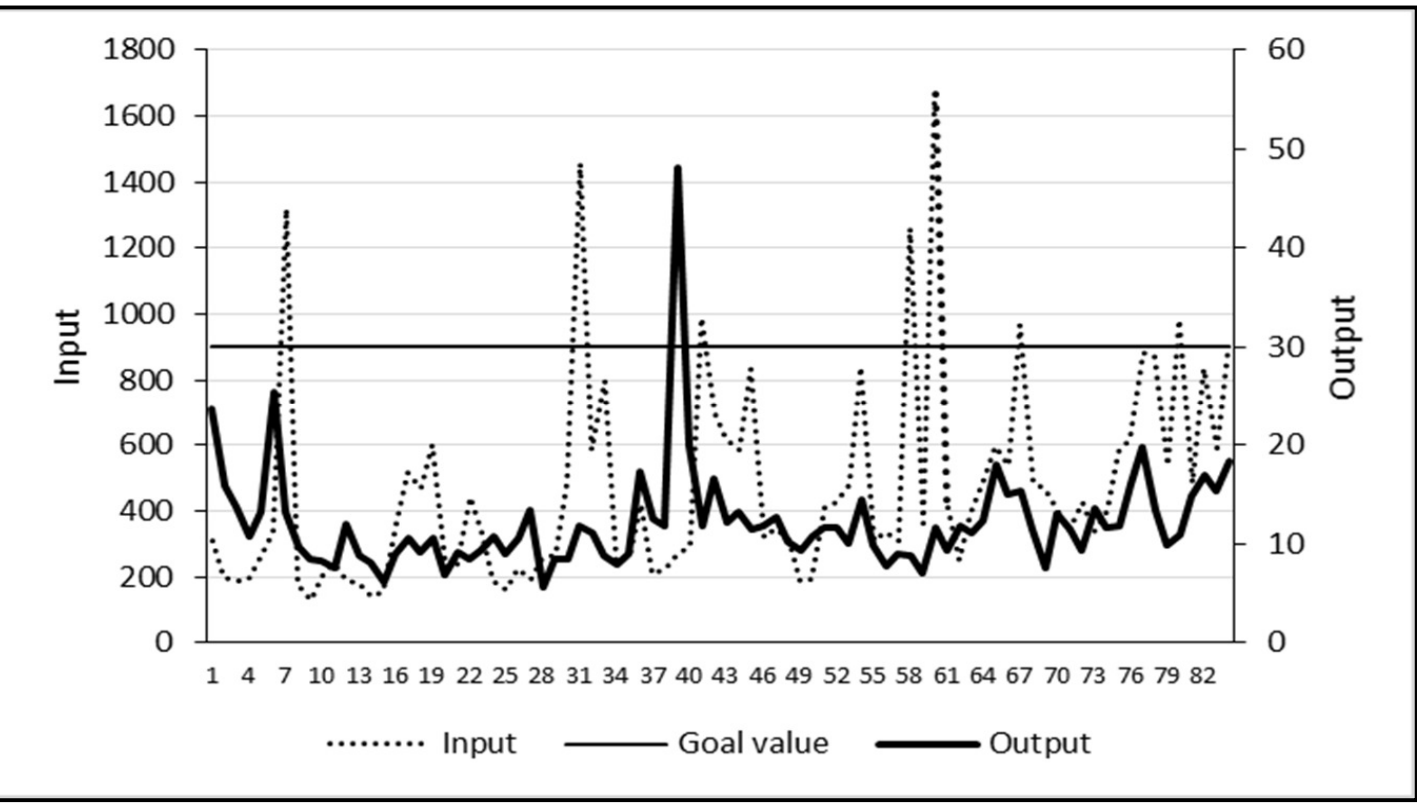

Figure 5. Monthly values of suspended matter input and output (mg/l), 2010-2016

Table 8. Variation coefficients of inputs and outputs of measured performances

\begin{tabular}{llccc}
\hline No. & Indicator & Average (mg/l) & Standard deviation (mg/l) & Variation coefficient (\%) \\
\hline 1I. & COD - input & 719.84 & 420.12 & $58.4 \%$ \\
1O. & COD - output & 36.91 & 18.05 & $48.9 \%$ \\
2I. & BOD - input & 259.81 & 133.62 & $51.4 \%$ \\
2O. & BOD - output & 5.63 & 2.63 & $46.8 \%$ \\
3I. & Nitrogen - input & 50.26 & 15.03 & $29.9 \%$ \\
3O. & Nitrogen - output & 9.97 & 2.74 & $27.5 \%$ \\
4I. & Phosphorus - input & 8.33 & 4.40 & $52.9 \%$ \\
4O. & Phosphorus - output & 0.80 & 0.49 & $61.2 \%$ \\
5I. & Suspended matter - input & 467.15 & 310.93 & $66.6 \%$ \\
5O. & Suspended matter - output & 12.18 & 5.40 & $44.3 \%$ \\
\hline
\end{tabular}

If the calculated $G$ value exceeds the critical value of the test, than we reject the null hypothesis and conclude that there is at least one significant maximal value over the average of the total period, which leads to alternation of all statistical results for they do not fit to the level of the set of other data. The test can be performed step-by-step, i.e. after excluding the first highest value, the procedure is repeated for the next highest value and so on. In our case, two extreme values were evidenced in the data series. For the complete data set the critical value of the Grubbs' test was 3.149, and after excluding the first highest value the critical value was 3.145 .

When observing input of different chemicals into the purification process, extreme values are of special interest, because the exploration of their causes is necessary, and one has to find out if there is any regular occurrence, or especially some 
periodical/seasonal patterns. Tracks of input values did not show any regular pattern of changing lower and higher values in time sequence, but two extreme values appeared, and that was in October and December 2014. These two months were critical concerning all the measured five performances. Extreme values were evidenced for COD (highest is $\mathrm{G}=4.32$ for December 2014, the next highest value is in October, and after elimination of data for December, we get $\mathrm{G}=4.54$ ). For BOD G-values are significant for December $(G=4.04)$ and statistically not significant for October, but still high (after elimination of the first highest value, $\mathrm{G}=2.76$ ). For nitrogen the most extreme values are in October 2014 $(G=3.61)$ and December same year (after exclusion of October, $\mathrm{G}=3.64$ ). With phosphorus, we found extreme values for December $2014(\mathrm{G}=4.66)$ and October (after exclusion of December, $\mathrm{G}=4.31$ ). Beside these two months characteristic to every performance, only one more extreme value was found, that is for BOD input in August $2016(\mathrm{G}=5.08)$.

As shown above, during the analyzed years extreme input values only are exceptional, but on the other side, the very inputs very often overcome the defined expected values. The next table indicates expected values of input, average input and number of measurements out of 84 exceeding the expected value.
Above presented data point to two very important conclusions:

- At first, the given wastewater purifying system is highly burdened with frequent too high input values. During the analyzed period exactly in $51 \%$ of measurements, the input values were higher than expected in average; this is why the mean values of measurements are greater than expected for every indicator.

- Secondly, the wastewater purification system is very effective through implementation of the "TO-BE" system, for despite high input values do not affect the resulting outputs, which are usually under the prescribed regulated desired upper level.

Observations of outputs gave the next results:

- Extremely high value of COD output is only found in January $2013(\mathrm{G}=7.54)$, when the removal efficiency was very low (59.22\%), but the system had immediate response and corrective actions were taken. All other output values of this indicator are under the goal value $(125 \mathrm{mg} / \mathrm{l})$. The efficiency of the system does not alter through the observed months, and there is not any significant trend in the data.

- The efficiency of the system is complete concerning output of BOC. In every month, the measured values are under the desired upper level $(20 \mathrm{mg} / \mathrm{l})$. In December 2012 the result is close to upper

Table 9. Indicators of inputs - expected values, averages and number of measurements over the expected value

\begin{tabular}{ccccc}
\hline No. & Measured indicator & $\begin{array}{c}\text { Expected value } \\
(\mathbf{m g} / \mathbf{l})\end{array}$ & $\begin{array}{c}\text { Average } \\
(\mathbf{m g} / \mathbf{l})\end{array}$ & $\begin{array}{c}\text { Number of measurements exceeding } \\
\text { expected value (out of 84) }\end{array}$ \\
\hline 1 & COD input & 500 & 719.84 & 48 \\
2 & BOD input & 250 & 259.81 & 36 \\
3 & Nitrogen input & 45 & 50.26 & 44 \\
4 & Phosphorus input & 7 & 8.33 & 35 \\
5 & Suspended matter output & 290 & 467.15 & 51 \\
\hline
\end{tabular}


bound and it appears to be an extreme value $(G=4.70)$, but this only is in statistical sense and do not have any practical implications.

- Series of data for output of nitrogen show substantial change in the second half of the total period compared to the first part of functioning the innovated purifying system. During the first 49 months (January 2010 January 2014), the results of measurements were almost in every case over the desired maximal value $(10 \mathrm{mg} / \mathrm{l})$ and the average was $11.64 \mathrm{mg} / \mathrm{l}$. In the second half of the period (beginning in February 2014), output values are always under the boundary and the average amounts to $7.64 \mathrm{mg} / \mathrm{l}$. This positive tendency of the system is expressed by a statistically significant decreasing trend (correlation coefficient between time units and output values of nitrogen $\mathrm{r}=0.68$, $\mathrm{p}<0.05)$.

- There are more variations in phosphorus output than with other indicators. Upper bound value is given as 1.0 $\mathrm{mg} / \mathrm{l}$ and this value was overcome during the first month of functioning of the system, even an extremely high value is evidenced (June 2010, $\mathrm{G}=4.26$ ), but stabilization is achieved after middle 2011. Output values are again raised during 2013, but after that, (2014-2016) values are again inside the desired intervals. Thanks to this, the average output value for phosphorus during the whole period is the acceptable $0.80 \mathrm{mg} / 1$.

- $\quad$ For suspended matters, the goal value is $30 \mathrm{mg} / \mathrm{l}$ and the objective is fulfilled reaching average of $12.18 \mathrm{mg} / 1$. Exception is March 2013, when the suspended matter output was very high, and it was as statistically, so practically an extreme value $(\mathrm{G}=6.67)$

For all five indicators correlation analysis was performed to study interconnections between input and output levels. There was no significant correlations, and this indicates the system is effective and successful, i.e. higher input values did not cause higher output values, and the results of purifying almost always meet the set standards.

\section{CONCLUSION}

The aim of this paper is to point out to the significance of implementing the transformation from functional to processoriented organization in which the management of products and services quality is going to be an ongoing process.

Based on the conducted research and the presented analysis it can be concluded that the average values of achieved efficiency in water purification process statistically highly significantly greater when applying the innovative "TO-BE" model compared to the application of the traditional "AS-IS" model. This applies to all five indicators. The highest relative improvement was achieved related to nitrogen (201\%) and phosphorus $(153 \%)$. For all five indicators correlation analysis was performed to study interconnections between input and output levels. There was no significant correlations, and this indicates the system is effective and successful. In the innovated process of wastewater treatment, the output from the process is treated wastewater, absolutely in accordance with the regulated standards.

This paper points out that enterprises engaged in wastewater treatment have to improve and systematize their knowledge on the business processes management. This is the only way that companies dealing with water treatment can make progress on their paths that lead to achieving the objectives of enterprise business, which is optimization of wastewater treatment to reduce costs and 
increase treatment process efficiency. This paper outlined some key facts regarding environmental protection in order to preserve it for future generations.

\section{References}

Ahmetagić, E., Piuković, B., \& Lukić, D. (2011). Business Process Management and Organization Innovativeness: Strategic management - International Journal of Strategic Management and Decision Support Systems in Strategic Management, 16 (4), 37-44.

Ahmetagić, E., Tumbas, P., \& Piuković, B. (2012). Business Process Management and Organization Innovativeness. Strategic management - International Journal of
Strategic Management and Decision Support Systems in Strategic Management, 16 (4), 47-53.

Anupindi, R., Chopra, S., Deshmukh, D.S., Van Mieghem, J.A., \& Zemel, E. (2012). Managing Business Process Flows. New Jersey, US: Pearson

Binner, H.F. (2011). Business Analyst und Business Process Professional. Journal Zeitschrift Führung und Organisation, 2011(2). 80-87.

Bladen C., Kennell J., Abson E., \& Wilde N. (2012). "Events management", Routledge Taylor \& Francis Group, London and New York.

Buh, B., Kovačič , A \& Indihar Štemberger M. (2015). Critical success factors for different stages of business process management adoption - a case study.

\section{ПОСЛОВНИ ПРОЦЕС ПОБОЉШАНОГ ТРЕТМАНА ОТПАДНИХ ВОДА: СМАҢИВАЊЕ РИЗИКА ОД ЗАГАЪЕЊА ОКОЛИНЕ}

\section{Блаженка Пиуковић Бабичковић, Жељко Војиновић, Бојан Лековић, Драго Цвијановић, Отилија Седлак, Зоран Ћирић}

\section{Извод}

Република Србија спада у групу европских земаља које очигледно имају проблеме са пречишћавањем отпадних вода. Главни циљ целокупног истраживања је указати на будућност организације процеса, као и на повезаност између спровођења концепта пословних процеса и постигнутог управљања перформансама, заснованог на специфичном примеру пречишћавања отпадних вода. За поступак пречишћавања отпадних вода, овај рад ће представљати модел „AS-IS“ који је примењен у условима функционалне организационе структуре, и „ТО-ВЕ“ модел, који је примењен унутар оријентације процеса. За оба модела дат је преглед постигнутих параметара добијених применом наведених модела. Наведени параметри указују на присуство загађивача у отпадним водама , након спроведеног процеса обраде, са описом како се то одражавало на ризик од загађења околине. Иновативни модел пречишћавања отпадних вода постиже знатно боље резултате, што је од великог значаја за заштиту животне средине. Конкретни докази о повећању хемијске потребе за кисеоником (COD), биолошкој потрошњи кисеоника (BOD), укупном азоту (TN), укупном фосфору (TP), уклањању укупних суспендованих чврстих материја (TSS), употребом ових модела, приказани су у овом раду.

Кључне речи: пречишћавање отпадних вода, пословни процес, ризик, заштита животне средине. 
Economic Research - Ekonomska Istraživanja, 28 (1) , 243-258.

Burlton, R.T., (2001). Business Process Management: Profiting from process. Indianapolis, Indiana, US: Sams Publishing.

Crosetto, G., \& Macazaga, J. (2005). The Process-Based Organization - A Natural Organization Strategy. Amherst, Massachusetts, US: HRD Press.

Drucker, P. (2005). Managing in the Next Society. Novi Sad, RS: Adizes. (In Serbian)

Darnton, G., \& Darnton M. (1997). Business Process Analysis. London, UK: International Thomson Business Press

Eicker, S., Kochbeck, J., \& Schuler, P.M. (2008). Employee Competencies for Business Process Management. Proceedings 11th International Conference Business Information Systems BIS 2008, Heidelberg, DE: Springer-Verlag. 251-262.

Grubbs, F. (1969). Procedures for Detecting Outlying Observations in Samples, Technometrics, 11(1). 1-21.

Haggstrom, C., \& Oscarsson, K. (2001). Making Companies More Efficient by Process Orientation - Describing and Mapping Core Processes. Goteborg/Stockholm, Sweden : Chalmers University of Technology and Royal Istitute of Technology.

Hammer, M., \& Champy, J. (2004). Reengineering the Corporation: A Manifesto for Business Revolution, Zagreb, HR: Mate ( In Croatian)

Hammer, M., \& Stanton, S. (2001). How Process Enterprises Really Work. Harvard Business Review, 77 (6) , 108-118.

Janićijević, N. (2010). Organizational Analysis and Change: A Process Aproach. Ekonomika preduzeća, 7-8, 305-316. (In Serbia)

Kravčenko, K.A. \& Mešalnik, V.P. (2011). The management of a large company.
Novi Sad, RS: Faculty of Technical Sciences (In Serbian).

Kuhn, T. (2011). Competitiveness based on business analysis. Journal of leadership and organization, 80(2), 94 (In German).

Lindfors, C. (2001). Process orientation: An approach for organisations to function effectively. In Proceedings of the Ninth International Group for Lean Construction Conference (Vol. 6, No. 8).

Nanz, G. (2011). Von den Unternehmenszielen zum Lastenheft. Journal Zeitschrift Führung und Organisation. 2011(2)., 88-93.

Naumenko, Lj. (2012), „Sewage treatment processing: useful experience and practical advice" - Project on urban reduction of eutrophication, PURE.

Ostroff, F. (1999), The Horizontal Organization. New York, US: Oxford University Press

Piuković Babičković B., Vojinović Ž., \& Vukadinović P. (2016). Innovative wastewater treatment as a prerequisite for the use of sludge in agriculture. Economics for Agriculture, 63 (2), 471-484.

Porter, M.E. (1985) Competitive Advantage: Creating and Sustaining Superior Performance. New York, US: The Free Press.

Program of economic reforms for period 2017.-2019.- Government Republic of Serbia

Rentzhog, O. (2000). Based companies of tomorrow: process oriented business philosophy. Novi Sad, Serbia: Prometej. (In Serbia)

Strategy of Wastewather Management for the period 2010 - 2019. (Sl. glasnik RS br. 29/10).

Fiskal strategy for 2017, Government Republic of Serbia. 